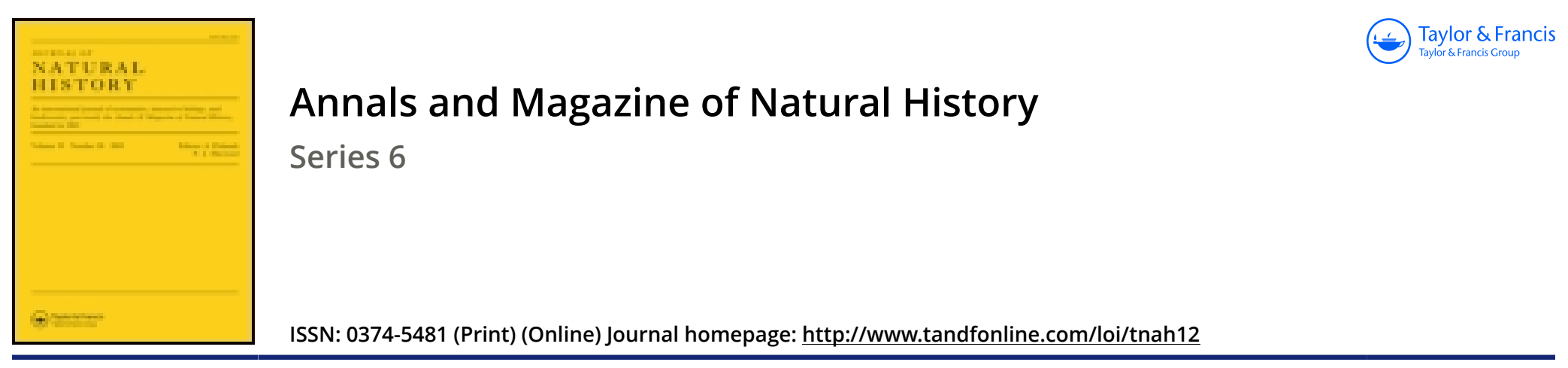

\title{
On a new myxosporidian of the family Glugeidæ
}

\section{Louis Léger}

To cite this article: Louis Léger (1897) On a new myxosporidian of the family Glugeidæ, Annals and Magazine of Natural History, 20:120, 556-557, DOI: $10.1080 / 00222939709487401$

To link to this article: http://dx.doi.org/10.1080/00222939709487401

$$
\text { 曲 Published online: } 06 \text { Oct } 2009 .
$$

Submit your article to this journal

LII Article views: 3

Q View related articles $\asymp$ 
of others, fighting against ignorance and superstition, may it be said-

"Some cherissannce it is to gentle mind,

When they have chevyced their land from bane,

When they are dead, they leave their name behind,

And their good deeds do on the Earth remain."

(Introduction to 'Ella': Chatterton.)

\section{MISCELLANEOUS.}

On a new Myrosporidian of the Famity Glugeïdæ. By Louis Léger.

THе larvæ of Simulizm (S. omatum, Meig.) abound at the commencement of spring in our swift-flowing French streams, and more particularly in those of the mountainous districts of the south. They are to be found in hundreds, placed side by side and attached by the anal region to stones or blades of grass, more especially in the places where the current is most disturbed.

If these clusters of larræ be examined with some little attention, one is struck with the very peculiar appearance presented by certain of them, in which the abdominal region is greatly swollen and of a milky-white colour, which offers a sharp contrast to the dusky green tint of the normal individnals. A careful dissection, performed under a lens, shows that these larræ contain in the body-cavity free parasitic masses each of which forms a kind of sac of an opaque white, with irregular contours. Certain larvæ contain but one of these masses, which fills the greater portion of the body-cavity, and thus attains a length of almost half a centimetre; others exhibit two or three of them-rarely more-which together fill up the vacant spaces of the body-carity, upon which to some extent they are moulded. Sumetimes, in the case of certain greatly diseased larvæ, the parasitie sac, owing to excessive growth, has distended the superficial integuments and canses a hernia on the surface of the larval abdomen in the shape of a large and nearly spherical cyst ; but most frequently the parasite in its growth simply compresses the organs of the body-cavity without injuring them in any way. Even the muscles are not injured, and the larva, though severely attacked, still exhibit very active movements. The fat-body alone appears excessively reduced and is often wanting, which leads to the belief that it is above all at its expense that the development of the parasite is effected. As for the digestive tract, this appears to be always immune in larvæ manifestly attacked by the parasites. On a single occasion I met with a young Myxosporidian still non-sporulated and forming a hernia on the external surface of the intestine, which shows that the migration of the vegetative stages from the alimentary canal into the coelome takes place at a very early period and rapidly.

On being examined under the microscope the parasitic masses appear as sacs with a delicate transparent wall, the interior of 
which is almost completely filled with a prodigious quantity of spores. The latter are ovoid and refringent, with a large vacuole at the swollen extremity. On being treated with iodine water they exhibit a filament fifteen or twenty times longer than themselves, which issues from their pointed extremity or summit. Here we have indeed the special characters of the spores of the Myxosporidia, and the presence of a single filament-analogous to that of which the lamented M. Thélohan was the first to succeed in demonstrating the existence in the case of Glugea bombycis-causes us to assign this parasite to the family Glugeidx.

The spores are of two different dimensions-the small ones measuring $4 \mu$ to $5 \mu$, the large about $8 \mu$. Certain sacs contain only microspores, and the latter are always united in little groups of eight and enclosed in a frail wall ; the others, on the contrary, contain only macrospores, and in this case the latter are united into spherical masses of different sizes, enclosing an indefinite number of spores, and likewise clothed with a delicate envelope. Together with these masses of spores we meet with the different phases of development of the primitive spherules - that is to say, of the spherical masses of granular protoplasm with one, two, four, eight nuclei, and so on, showing the different stages in the formation of the spores.

The characters of this Myxosporidian place it in the genus Glugea by the side of the other species studied by Thélohan and formerly included in the group Microsporidia. It is distinguished from the forms at present known-(1) by its habitat being exclusively confined to the body-cavity, without relations with the alimentary canal at maturity or with the other organs which always remain intact; (2) by the faculty it possesses of appearing sometimes in the form of cysts with an indeterminate number of macrospores, and sometimes in the condition of cysts enclosing only eight microspores, which shows that these two states are far from having the specific importance attached to them at present.

I shall designate the species Glugea varians, in order to recall this latter peculiarity.

When this Myxosporidian appears, as is most frequently the case, in the form of cysts containing eight spores, one cannot help noticing its striking analogy to Telohania Contejeani, Henneguy, which completely invades the muscles of the crayfish and causes the death of this crustacean.

As I thought that there might be some relation between these two parasites, especially considering the fact that the Simuliumlarvæ are frequently met with in the streams inhabited by crayfish, I attempted, in collaboration with Dr. Hagenmüller, to infest crayfish artificially by causing them to consume infected larvæ. Hitherto our experiments have not yielded positive results. Perhaps the spores only recover their virulence provided they pass into the intestine of a vertebrate, as Krassilschtchik maintains in the case of the Glugea of the Bombyx. We shall attempt to verify this subsequently.-Comptes Rendus, t. cxxv. no. 4 (July 26, 1897), pp. $260-262$. 